\title{
Expectations and Experiences of Technology-Rich Classrooms of Preservice and In-service Teachers in China
}

\author{
Baoping $\mathrm{Li}^{1,2}$ \& Guoqing Zhao ${ }^{2}$ \\ ${ }^{1}$ Advanced Innovation Center of Future Education, Beijing Normal University, Beijing, China \\ ${ }^{2}$ Faculty of Education, Beijing Normal University, Beijing, China \\ Correspondence: Baoping Li, Faculty of Education, Beijing Normal University, Beijing, China. Tel: \\ 86-10-5880-8316. E-mail: libp@bnu.edu.cn
}

Received: December 2, 2019

Accepted: December 11, 2019

Online Published: December 17, 2019

doi:10.20849/jed.v3i3.673

URL: https://doi.org/10.20849/jed.v3i3.673

\begin{abstract}
Technology-Rich Classrooms (TRCs) have been increasingly constructed in K12 schools. Existing studies revealed that to what extent TRCs play a role in shaping teaching and learning depends on what teachers expect to do and what they do with TRCs. This study aimed at exploring the gap between teachers' experiences of existing TRCs and their expectations of ideal TRCs. A total of 194 preservice teachers studying at Beijing Normal University (BNU) and 149 in-service teachers who enrolled in a master program at BNU participated in the study. The Smart Classroom Inventory (SCI) a ten-component inventory revised from the previous study, was used to collect the data. Independent-samples t-tests and paired-samples t-tests revealed that: (a) both preservice teachers and in-service teachers reported significantly lower experiences of TRCs than their expectations of ideal ones in terms of most dimensions, with the only exception that preservice teachers' Technology usage. (b) Whether in existing TRCs, or in ideal ones, both preservice teachers and in-service teachers reported relative lower scores of Flexibility, Learning data, Differentiation, Investigation, and Cooperation than other dimensions. (c) Preservice teachers reported significantly higher scores of Flexibility, Technology usage, Learning data, Differentiation, Investigation, and Cooperation than in-service teachers, while in-service teachers reported significantly higher scores of Physical design, Student Cohesiveness, Equity, and Learning experiences than preservice teachers.4) Preservice teachers reported significantly higher expectation of ideal Physical design, Differentiation than in-service teachers, while they reported significantly lower expectations of ideal Flexibility, Student Cohesiveness, Equity, and Learning experience than in-service teachers. Implications for preservice teachers' education and in-service teachers' professional development were discussed.
\end{abstract}

Keywords: technology-rich classrooms, expectations, experiences, data literacy, space literacy, teacher education in China

\section{Introduction}

A Technology-Rich Classroom (TRC) is defined as the classroom equipped with emerging information technologies (Dwyer, Ringstaff, \& Sandholtz, 1991). A typical TRC comprises a wireless network, a 1:1 portable computer, a digital learning environment, an instant response system, a multi-screen, and other movable furniture (Elstad \& Christophersen, 2017; J. Yang \& Huang, 2015; J. Yang, Yu, Gong, \& Chen, 2017). As Dewey indicated, teachers never teach students directly, but teach them indirectly by means of the educative environment (Hansen, 2002). By utilizing emerging technologies in TRCs like education robot, virtual reality, 3D avatars, and wireless sensors, diversified innovative teaching and learning activities have been held in TRCs (Fuad, Deb, Etim, \& Gloster, 2018; Hwang, Chu, Shih, Huang, \& Tsai, 2010; Lemmon, Lui, Cottrell, \& Hamilton, 2012; Liao, Sunq, Wang, \& Lin, 2019; Omokawa, Kobayashi, \& Matsuura, 2019). These activities can stimulate students' learning motivation, improve students' learning experience, promote students' active learning behaviour, help students achieve good learning performance, and cultivate the 21st-century skills (Liu, Horton, Olmanson, \& Toprac, 2011; O'Grady, Simmie, \& Kennedy, 2014). As a result, TRCs are considered as a kind of promising learning environments in the digital era.

Many countries have begun to design and construct TRCs in K12 schools. For example, Technology-Rich Classrooms Program in Kansas aimed to improve students' academic achievement using technology in elementary and secondary schools (Hare, Ault, \& Niileksela, 2011). The "Up-Scaling Creative Classrooms in 
Europe" (CCR) project conceptualized the future learning environments, which have fully embedded the ICT to innovate teaching and learning inside or outside the classrooms (Bocconi, Kampylis, \& Punie, 2012). Similarly, with a hope to change the traditional way of teaching, K-12 schools in China have attached great importance to construct TRCs since the first decade in the 21 st century.

\subsection{Professional Development Programs on TRCs}

TRCs are a kind of higher level of digital classrooms, and the most notable physical environments of TRCs is the variety of emerging technical equipment. The technical equipment can interact with teachers and students by means of demonstrating learning resources, designing learning tasks, and providing feedback to learning performance. The technical equipment replaces part of knowledge transferring and learning performance evaluation works that have been done by teachers in traditional classrooms, so it gives the teachers the opportunity to focus on achievement of advanced cognitive skills in TRCs. The technical equipment is looked as a key factor for transforming teacher-centred pedagogy to student-centred pedagogy. Researches stated that the technology literacy (Dinçer, 2018), technology self-efficacy (Parkman, Litz, \& Gromik, 2018), and the application level of digital technology (Elstad \& Christophersen, 2017) could affect the instruction level in TRCs. The information technology skills are important contents of teacher training for TRCs.

Besides technology matters, the experienced teachers at schools and teacher educators at higher educational institutes have been looked like a key role in ensuring that all teachers use active learning. As a result, it is critical to equip both preservice teachers and in-service teachers with the skills of teaching in the TRCs (Niemi, 2002). However, some researchers found that, preservice teachers are difficult to conduct the student-centred pedagogy in the future in their own classrooms due to their prior experience in more teacher-oriented classrooms (Zeki \& Güneyli, 2014). Kennedy-Clark (2011) stated that many preservice teachers tend to maintain an ideological underpinning for their teaching, such as facilitating a student-centred classroom, yet when they enter the classroom they tend to use teacher-centred approaches. Obviously, it is a big challenge to train the preservice teachers to choose student-centred pedagogy and conduct the self-regulated learning activities in the TRCs.

\subsection{Teachers' Perception of TRCs and Effects on Their Teaching}

In addition to the knowledge, some environmental designing themselves maybe prevented teachers from applying innovative teaching methods in TRCs properly. Watson, Mong, \& Harris (2011) noted that some perceived hurdles, such as fixed class schedules and lack of support, may impede game or virtual world uptake in education, although the classroom teachers were amenable to using games in the classroom. Such teaching situation can be explained by the formula which proposed by Lewin (1946). The formula $B=f(P, E)$ describes the factors which effect the choice of human behaviour, it indicates that the person's individual characteristic (P) and their interaction with the environments (E) to be the potent determinants of human behaviour (B). The classroom is a typical learning environment in school where teaching and learning activities occurred. Lewin's formula provides a view for interpreting the factors which influence the teacher's pedagogical behaviour in TRCs besides of technical and pedagogical training.

Ahmad, Osman, \& Halim (2013) stated that 'teachers' needs with regard to physical aspects of their environment are fulfilled, and exposure to the latest teaching techniques is increased, the teacher might be able to teach science effectively". Some research believes that the teachers' psychological perception level and acceptance level of TRCs should be considered when training the teachers to master innovative instructional method (de Winter, Winterbottom, \& Wilson, 2010). Based on Lewin's formula, if the improvement of teachers' technical literacy and pedagogical knowledge are regarded as strengthening the teachers' individual characteristic $(\mathrm{P})$, then guide teachers to perceive the TRCs in a properly way can be looked as strengthening the factor of environments(E). The TRCs have made big difference in physical appearance of classrooms and the relationship between students and teachers, but only the teachers who are aware of the changes can innovate the teaching mode. $\mathrm{Li}$ (2015) found that perceived level of learning data usage and the relationship between students and teachers are the intermediary of integrate the teachers' technology literacy into their adoption of active teaching and learning strategies in the TRCs. So teachers' professional development programs need to address attitudes and perceptions as well as skills development to mitigate attitudinal barriers to the use of ICT in a classroom (Pierce and Ball 2009).

\subsection{Research Questions}

Existing research has revealed that to what extent TRCs play a role in shaping teaching and learning depends on what teachers expect to do, and what they do with them (Inan \& Lowther, 2010; Parkman, Litz, \& Gromik, 2018; Robinson, 2003). Particularly, teachers' psychological perception of the learning technology, learning platform and the arrangement of learning space in TRCs play an important role in teachers' choice of their teaching 
methods (Li, 2015). Researches also indicated that K-12 teachers had not been well prepared to teach with TRCs (Elstad \& Christophersen, 2017). However, research revealing K12 teachers' expectation of and their perceived affordances of TRCs are still lack.

This study aimed at exploring preservice and in-service K-12 teachers' expectations of ideal TRCs and experiences of existing ones. Specifically, this study aimed at examining the gap between the TRCs their expectations and their experiences of TRCs from both preservice teachers' and in-service teachers' perspectives and examining different views of these two groups of teachers' on TRCs. This study attempted to answer the following research questions:

1) Is there significant differences in expectations and experiences of TRCs between preservice teachers and in-service teachers?

2) Is there a significant gap between experiences of existing TRCS and their expectations of ideal ones?

\section{Method}

\subsection{Participant (Subject) Characteristics}

A total of 194 preservice teachers studying at BNU and 149 in-service teachers who enrolled in a master program at BNU participated in the study. In this study, preservice teachers referred to undergraduate or graduate students who were majoring in education but had not yet served as professional teachers, while in-service teachers referred to those who had served as professional teachers. The demography of the participants was shown in Table 1.

Table 1. Demographic information of the participants

\begin{tabular}{lllll}
\hline Participants & Characteristics & Categories & Frequency & Percentage (\%) \\
\hline In-service & Gender & Female & 82 & $55.04 \%$ \\
teachers(n=149) & & Male & 67 & $44.96 \%$ \\
& \multirow{2}{*}{ Age } & Under 25 years old & 23 & $15.43 \%$ \\
& & $26-35$ years old & 67 & $44.97 \%$ \\
& \multirow{4}{*}{ Teaching experience } & 36-51 years old & 59 & $39.60 \%$ \\
& & Under 3 years & 31 & $20.81 \%$ \\
& & $4-10$ years & 47 & $31.54 \%$ \\
& & $10-20$ years & 64 & $42.95 \%$ \\
Preservice & More than 20 years & 7 & $4.70 \%$ \\
teachers & Type of school & Elementary school & 78 & $52.35 \%$ \\
$(\mathrm{n}=194)$ & Gender & Secondary school & 71 & $47.65 \%$ \\
& \multirow{3}{*}{ Age } & Female & 148 & $76.29 \%$ \\
& & Male & 46 & $23.71 \%$ \\
& & Under 20 years old & 71 & $36.60 \%$ \\
& Learning experience & Bachelor's degree & 142 & $73.20 \%$ \\
& & Master's degree & 52 & $26.80 \%$ \\
\hline
\end{tabular}

\subsection{Instruments}

The Smart Classroom Inventory (SCI) developed by Li, Kong, \& Chen (2015) was used to collect the data. The SCI measures preservice or in-service teachers' perception of physical environments, pedagogical paradigm, and relationship in TRCs. The SCI consists of 10 subscales, namely Physical design, Flexibility, Technology usage, Learning data, Differentiation, Investigation, Cooperation, Students cohesiveness, Equity, and Learning experience. The description of each subscale was shown in Table 2. 
Table 2. Description of the scales of Smart Classroom Inventory (SCI)

\begin{tabular}{|c|c|c|}
\hline Scale Name & Scale Description & Sample Items \\
\hline Physical design & $\begin{array}{l}\text { The extent to which the spatial area, } \\
\text { furniture equipment, and information } \\
\text { technology infrastructure of smart } \\
\text { classrooms. }\end{array}$ & $\begin{array}{l}\text { Students have adequate workspace for } \\
\text { putting textbooks, tablet PCs and } \\
\text { other resources. }\end{array}$ \\
\hline Flexibility & $\begin{array}{l}\text { The extent to which the comfortable } \\
\text { support for users by classroom } \\
\text { environment. }\end{array}$ & $\begin{array}{l}\text { The classroom can be a theater, a } \\
\text { group working place or other scenes } \\
\text { for different learning purposes. }\end{array}$ \\
\hline Technology usage & $\begin{array}{l}\text { The extent to which teachers use } \\
\text { information technology as a tool to } \\
\text { instruct and to access information. }\end{array}$ & $\begin{array}{l}\text { I deal with my assignments using } \\
\text { computer or other digital devices. }\end{array}$ \\
\hline Learning data & $\begin{array}{l}\text { The extent to which the information } \\
\text { technology was used to acquire and } \\
\text { compute the learning data of the } \\
\text { students. }\end{array}$ & $\begin{array}{l}\text { I can find out students' learning } \\
\text { history, like homework, and } \\
\text { discussions in the last semester using } \\
\text { computers or other digital devices. }\end{array}$ \\
\hline Differentiation & $\begin{array}{l}\text { The extent to which teachers cater for } \\
\text { students differently on the basis of } \\
\text { ability, rates of learning and interests. }\end{array}$ & Students can learn at their own pace. \\
\hline Investigation & $\begin{array}{l}\text { The extent to which skills and processes } \\
\text { of inquiry and their use in problem } \\
\text { solving and investigation are } \\
\text { emphasized. }\end{array}$ & $\begin{array}{l}\text { Students carry out investigations to } \\
\text { test their ideas. }\end{array}$ \\
\hline Cooperation & $\begin{array}{l}\text { The extent to which students cooperate } \\
\text { with one another on learning tasks. }\end{array}$ & $\begin{array}{llr}\text { Students } & \text { can cooperate with } \\
\text { somebody outside } & \text { the classroom } \\
\text { through Internet } & \text { when doing } \\
\text { assignment work. } & & \end{array}$ \\
\hline Student cohesiveness & $\begin{array}{l}\text { The extent to which students know, help } \\
\text { and are supportive of teacher. }\end{array}$ & I am friendly to students of the class. \\
\hline Equity & $\begin{array}{l}\text { The extent to which students are treated } \\
\text { equally by the teacher. }\end{array}$ & $\begin{array}{l}\text { I treat each student in the same way } \\
\text { as other students in this class. }\end{array}$ \\
\hline Learning experience & $\begin{array}{l}\text { The extent to which students' } \\
\text { satisfaction and some special learning } \\
\text { experience in smart classroom. }\end{array}$ & $\begin{array}{l}\text { The devices and software help } \\
\text { students to get hands-on experience } \\
\text { with the learning objects or learning } \\
\text { context. }\end{array}$ \\
\hline
\end{tabular}

To acquire a comprehensive understanding of teachers' view of TRCs, the questionnaire included three sections: the Participants' basic information, Experiences of existing TRCs (Existing form), and Expectations of ideal TRCs (Ideal form). The Existing form asked about teachers' perceptions of existing TRCs that they have experienced, and the Ideal form asked about teachers' expectations about the ideal TRCs. All items were designed on a 5-point Likert scale from 1 "almost never" to 5 "almost always."

\subsection{Data Analysis}

All the data were analysed by SPSS 21.0. Independent-samples t-tests were used to compare the differences between the perceptions of preservice teachers and in-service teachers and paired-samples t-tests were used to compare the differences between teachers' experiences of existing TRCs and expectation of ideal ones.

\section{Results}

\subsection{Validation of the Instruments}

Internal reliability was tested using the individual learner as a unit of analysis for the Cronbach's alpha coefficient. As shown in Table 3, in Existing form, the Cronbach's alpha coefficient of preservice teachers is 0.90, and 0.96 of in-service teachers, the Cronbach's alpha coefficients of each subscale ranged from 0.48 to 0.85 of preservice teachers, and ranged from 0.67 to 0.95 of in-service teachers. In Ideal form, the Cronbach's alpha coefficient of preservice teachers is 0.92 , and 0.98 of in-service teachers, the Cronbach's alpha coefficients of each subscale ranged from 0.43 to 0.85 of preservice teachers, and ranged from 0.63 to 0.97 of in-service teachers. 
Table 3. Cronbach's alpha coefficient of both forms for preservice teachers and in-service teachers

\begin{tabular}{lllll}
\hline Factors and Items & \multicolumn{2}{l}{ Preservice $(\mathrm{n}=194)$} & \multicolumn{2}{l}{ In-service(n=149) } \\
\hline & Existing & Ideal & Existing & Ideal \\
\hline Physical design & 0.71 & 0.68 & 0.67 & 0.86 \\
Flexibility & 0.48 & 0.43 & 0.71 & 0.63 \\
Technology usage & 0.83 & 0.84 & 0.90 & 0.93 \\
Learning data & 0.50 & 0.43 & 0.85 & 0.94 \\
Differentiation & 0.85 & 0.82 & 0.92 & 0.93 \\
Investigation & 0.80 & 0.85 & 0.95 & 0.97 \\
Cooperation & 0.62 & 0.80 & 0.84 & 0.88 \\
Student cohesiveness & 0.70 & 0.76 & 0.74 & 0.92 \\
Equity & 0.66 & 0.76 & 0.71 & 0.81 \\
Learning experience & 0.76 & 0.76 & 0.77 & 0.92 \\
\hline
\end{tabular}

\subsection{Gaps Between Existing TRCs and Ideal TRCs}

The paired sample t-test was conducted between the Existing $\mathrm{s}$ form and Ideal form of both teacher groups to test the differences between experiences of existing TRCs and expectation of ideal TRCs. As Table 4 and 5 shown that except the Technology usage scale of preservice teachers, each scale has significant differences between the two forms. The result stressed the great gap between the existing TRCs and ideal TRCs.

Table 4. Comparison of preservice teachers' experiences and expectation of TRCs(n=194)

\begin{tabular}{llllll}
\hline Subscale & \multicolumn{2}{l}{ Existing } & \multicolumn{2}{c}{ Ideal } & $\mathrm{t}$ \\
\cline { 2 - 6 } & $\mathrm{M}$ & $\mathrm{S} . \mathrm{D}$. & $\mathrm{M}$ & $\mathrm{S} . \mathrm{D}$. & \\
\cline { 2 - 6 } Physical design & 3.24 & 0.82 & 4.50 & 0.62 & $-18.22^{* * *}$ \\
Flexibility & 3.06 & 0.86 & 3.87 & 0.80 & $-10.30^{* * *}$ \\
Technology usage & 3.90 & 0.74 & 3.95 & 0.88 & -0.86 \\
Learning data & 2.63 & 0.91 & 3.70 & 0.76 & $-14.53^{* * *}$ \\
Differentiation & 2.71 & 0.87 & 4.18 & 0.77 & $-19.13^{* * *}$ \\
Investigation & 3.18 & 0.75 & 3.92 & 0.80 & $-13.31^{* * *}$ \\
Cooperation & 3.15 & 0.77 & 3.87 & 0.88 & $-13.29^{* * *}$ \\
Students cohesiveness & 3.58 & 0.90 & 4.16 & 0.83 & $-11.20^{* * *}$ \\
Equity & 3.04 & 0.90 & 3.82 & 1.01 & $-11.30^{* * *}$ \\
Learning experience & 3.31 & 0.91 & 4.18 & 0.80 & $-12.76^{* * *}$ \\
\hline Note $* * * p<.001$ & & & & &
\end{tabular}

Table 5. Comparison of in-service teachers' experiences and expectation of TRCs $(n=149)$

\begin{tabular}{llllll}
\hline Subscale & Existing & & \multicolumn{2}{l}{ Ideal } & $\mathrm{t}$ \\
\hline Physical design & $\mathrm{M}$ & S.D. & $\mathrm{M}$ & $\mathrm{S} . \mathrm{D}$. & \\
Flexibility & 3.46 & 0.86 & 4.29 & 0.86 & $-7.36^{* * *}$ \\
Technology usage & 2.82 & 1.23 & 4.06 & 0.90 & $-9.32^{* * *}$ \\
Learning data & 2.85 & 1.10 & 3.93 & 1.03 & $-6.69^{* * *}$ \\
Differentiation & 2.36 & 1.14 & 3.84 & 1.22 & $-9.45^{* * *}$ \\
Investigation & 2.67 & 1.02 & 3.94 & 1.06 & $-9.61^{* * *}$ \\
Cooperation & 2.88 & 1.02 & 4.08 & 1.03 & $-8.61^{* * *}$ \\
Students cohesiveness & 2.82 & 0.95 & 4.07 & 0.99 & $-9.65^{* * *}$ \\
Equity & 3.94 & 0.74 & 4.50 & 1.02 & $-6.08^{* * *}$ \\
Learning experience & 3.91 & 0.66 & 4.45 & 0.62 & $-8.04^{* * *}$ \\
\hline
\end{tabular}

Note $* * * \bar{p}<.001$ 


\subsection{Differences Between Preservice and In-service Teachers}

The Mean, Standard Deviation (SD), and t-test for both teachers preservice and in-service teachers' perception of TRCs in both Existing and Ideal forms are respectively shown in Table 6 and Table7. All the subscales have significant differences between preservice teachers and in-service teachers in perceived form. In Existing form, the preservice teachers give the highest score in Technology usage in TRCs, the in-service teachers give the highest score in Student cohesiveness, and both teachers give the lowest score in Learning data.

Table 6. Comparison of preservice and in-service teachers' experiences of TRCs in existing form

\begin{tabular}{|c|c|c|c|c|c|}
\hline \multirow[t]{2}{*}{ Subscale } & \multicolumn{2}{|c|}{ Preservice $(n=194)$} & \multicolumn{2}{|c|}{ In-service $(n=149)$} & \multirow[t]{2}{*}{$\mathrm{T}$} \\
\hline & $\mathrm{M}$ & S.D. & $\mathrm{M}$ & S.D. & \\
\hline Physical design & 3.24 & 0.82 & 3.46 & 0.86 & $20.49 * * *$ \\
\hline Flexibility & 3.06 & 0.86 & 2.82 & 1.23 & $24.53 * * *$ \\
\hline Technology usage & 3.90 & 0.74 & 2.85 & 1.10 & $25.84 * * *$ \\
\hline Learning data & 2.63 & 0.91 & 2.36 & 1.14 & $22.52 * * *$ \\
\hline Differentiation & 2.71 & 0.87 & 2.67 & 1.02 & $19.05^{* * *}$ \\
\hline Investigation & 3.18 & 0.75 & 2.88 & 1.02 & $22.82 * * *$ \\
\hline Cooperation & 3.15 & 0.77 & 2.82 & 0.95 & $23.89 * * *$ \\
\hline Student cohesiveness & 3.58 & 0.90 & 3.94 & 0.74 & $-16.93 * * *$ \\
\hline Equity & 3.04 & 0.90 & 3.91 & 0.66 & $-9.79 * * *$ \\
\hline Learning experience & 3.31 & 0.91 & 3.75 & 0.81 & $-4.72 * * *$ \\
\hline
\end{tabular}

In the Ideal form, except Technology usage, Learning data, and Investigation, all the other scales have significant differences between preservice and in-service teachers. Preservice teachers have the highest expectations for the Physical design of TRCs, in-service teachers have the highest expectation for the Student cohesiveness, and Learning data get the lowest score from both teacher groups.

Table 7. Comparison of preservice and in-service teachers' expectation of TRCs in ideal form

\begin{tabular}{llllll}
\hline Subscale & \multicolumn{4}{l}{ Preservice $(\mathrm{n}=194)$} & \multicolumn{2}{l}{ In-service $(\mathrm{n}=149)$} & $\mathrm{T}$ \\
\hline Physical design & $\mathrm{M}$ & $\mathrm{S} . \mathrm{D}$. & $\mathrm{M}$ & $\mathrm{S} . \mathrm{D}$. & \\
Flexibility & 4.50 & 0.62 & 4.29 & 0.86 & $2.50^{*}$ \\
Technology usage & 3.87 & 0.80 & 4.06 & 0.90 & $-1.97^{*}$ \\
Learning data & 3.95 & 0.88 & 3.93 & 1.03 & -0.26 \\
Differentiation & 3.70 & 0.76 & 3.84 & 1.22 & -1.33 \\
Investigation & 4.18 & 0.77 & 3.94 & 1.06 & $2.39^{*}$ \\
Cooperation & 3.92 & 0.80 & 4.08 & 1.03 & -1.56 \\
Student cohesiveness & 3.87 & 0.88 & 4.07 & 0.99 & $-2.01^{*}$ \\
Equity & 4.16 & 0.83 & 4.50 & 1.02 & $-3.27^{* *}$ \\
Learning experience & 3.82 & 1.01 & 4.45 & 0.62 & $-6.54^{* * *}$ \\
\hline
\end{tabular}

Note $* p<.05, * * p<.01, * * * p<.001$ 


\section{Discussion}

\subsection{Both Teacher Groups' Experiences and Expectation of Learning Data and Learning Space}

Differed with the digital classrooms which only equipped with large screen and computers for teachers, a critical feature of TRCs is the multiple smart terminals equipped for students and the flexible space design (Bocconi, Kampylis, \& Punie, 2012; Yau, Gupta, Karim, Ahamed, Wang, \& Wang, 2003). The terminals can support various interaction activities among students, teachers and learning platforms, record, analyse the learning data to give students and teachers individual guidance. It is a critical feature and an inevitable trend that massive data analysis and data mining will be widely applied in the TRCs (Chen, Cheng, \& Chew, 2016; Lin, Huang, \& Cheng, 2010; Y. Yang, Leung, Yue, \& Deng, 2013). The flexible space design can rearrange the classroom to adapt to the teaching and learning activities. The terminals and flexibility in TRCs are the important basis for carrying out innovative learning in a sense.

The result of the survey shows that both preservice and in-service teachers give a relatively low score in the subscale of Flexibility and Learning data in their both perceived perception and belief of TRCs. The result indicates that 1) both teachers do not aware of the biggest possible change in their future teaching works 2) the data literacy and space literacy should be added to the teachers' education and professional development.

Data literacy is the ability to read, work with, analyse, and argue with data. Teachers working in TRCs should have been capable of properly understand what the data means, including how to read graphs and charts appropriately, and then draw correct instruction decisions from data (Gummer \& Mandinach, 2015; Shields, 2005). To help the teachers in adapting to the data-driven practice in TRCs, the courses on the topic or integrate data-driven concepts into existing courses should be design and developed (Mandinach \& Gummer, 2013).

Space literacy is generally defined as the ability how we understand and interact with the physical world in which we live, in the field of education this topic is always discussed in the Geometry, Mathematics and other related subjects learning (Moore-Russo, Viglietti, Chiu, \& Bateman, 2013).

Understanding the contexts for learning is important for students' literacy cultivating, and learning space is an important element in the education ecology, the learning space affects the type of pedagogical approach, student learning outcomes and student perceptions of the Learning experience (Nichols, 2011; Walker, Brooks, \& Baepler, 2011). So, this research tries to extend the meaning of space literacy to the ability the teacher can identify, redesign, and integrate the furniture and space into their pedagogy.

In the existing researches, technology literacy was taken as an influencing factor for applying TRCs into the education of preservice teachers (Dinçer, 2018). A simple technical training does not necessarily lead to better learning outcomes, in TRCs the critical support for the innovative instruction approaches lies in the further application of learning data that generated during the whole teaching and learning process. The activities of inquiry learning, gamification learning, and group learning need to add consideration to the learning space besides technical support. The application of learning data and design the learning space are now neglected by Chinese teacher education, and those contents should be added to current teacher education system in China.

\subsection{The Differences in Experiences and Expectation of the TRCs Between Both Teacher Groups}

It was shown in Table 6 and Table7 that there were significant differences between the preservice teachers and in-service teachers in both Existing and Ideal forms of TRCs.

Preservice teachers had more positive experiences of technology environments and pedagogy than in-service teachers and a more negative experiences of the relationship than in-service teachers in the TRCs in existing situations while the preservice teachers got lower scores in all the subscales except the subscale of Physical design and Differentiation than the in-service teacher in their expectation of the TRCs.

Preservice teachers from normal universities which belong to Chinese Ministry of Education have the opportunity to train constructive instruction methods in new type of classrooms (Yi, Chao, Ge, \& Fan, 2010), they have higher experiences of Flexibility of learning space, Technology usage, Differentiation, Investigation, and Cooperation than in-service teachers. The in-service teachers come from all levels of schools, and the experiences of real classrooms is relatively low. However preservice teachers are lack of understanding of the entire learning ecology, in addition, as a digital generation, the proportion of preservice teachers' interpersonal communication online is getting larger, while face to face interactive experience is less than that of in-service teachers. These reasons lead to the fact that in the subscales of the emotional relationship like Student cohesiveness, Equity, and Learning experience in both Existing and Ideal form, the preservice teachers' experiences are lower than that of in-service teachers. 
The understanding the importance of students' emotional needs and be fair to each member of the class is the basis of transforming teacher-centred instruction to student-centred instruction. The content of class management and teaching organization under the student-centred education mode also should be added to the teachers training.

\subsection{The Features of the Preservice Teachers' Experiences and Expectation of TRCs}

As shown in Table 4, in the existing form, preservice teachers have a higher experiences of the ICT support of their learning and relationship with others. In Chinese universities, the members of the class are basically fixed, and students always live together in the campus, so they have much more opportunities to establish friendly relations, and those relations can extend into their learning activities. In recent years, mobile phones and social networks like WeChat are widely used by some university teachers to carry out some learning activities outside the classrooms. This hybrid learning helps preservice teachers get the high experiences of technology usage in their learning at one hand and on the other hand, it strengthened online communication between teachers and students.

The scores of such active teaching approach as Differentiation, Investigation, and Cooperation were relatively lower. In the TRCs, students can acquire learning resource in an open learning context, and do a lot of knowledge building tasks independently, and the student-centred classroom ecology should be cultivated. However, as accustomed to the teacher-centred teaching approaches, teachers indicated many constraints and restrictions to choose the inquiry-oriented and project-based approaches as their day-to-day teaching approaches (O’Grady, Simmie, \& Kennedy, 2014). Preservice teachers get a lower experiences of the pedagogical activities which they accepted in their training lessons. Some defects in the current teacher training systems were exposed in the survey.

The contrast between real experiences and expectation of TRCs inferred that preservice teacher was lack of confidence in teaching in the TRCs in the future. In current Chinese preservice teachers' training system, subject's knowledge, the technology usage knowledge, and technology integrated pedagogy knowledge are taught by different departments and institute respectively. There is a lack of connection and integration between different learning content. Educational internships are often on the eve of graduation when all the courses are completed. The preservice teachers do not have the opportunity to learn some new courses with teaching experience after the educational internship, and it is difficult for them to verify and reflect the content during their course learning. Preservice teachers are digital natives (Prensky, 2001), they still identified more obstacles to using active learning than in-service teachers. The preservice teachers should learn ICT in a contextually, and look the ICT as both accessible and worthwhile, rather than just as a box-ticking activity to show that they have achieved graduate standards (de Winter, Winterbottom, \& Wilson, 2010; Kennedy-Clark, 2011; O'Grady, Simmie, \& Kennedy, 2014). This is the challenge to current teaching training system in China.

\subsection{Limitations and Future Work}

This study yields to some limitations. The first limitation of this study is that a self-report survey was used to collect the data. The second limitation of the study is that many participants have not had experiences in teaching with TRCs. Further study could collect more fruitful data to deepen these findings.

\subsection{Implication for Practice}

Findings from this study have several implications for the integration of technology in the TRCs. It indicated that 1) Data literacy and space literacy should be the new competency of teachers in TRCs while contents should be added to the teachers training system. 2) The training system of preservice teachers should be more integrated, and the curriculum should be integrated with the educational internship to increase the contextualization of learning.3) Guide student teachers to learn to design their teaching activities by considering the different cultural backgrounds of students and the relationship between teachers and students in their classrooms.

\section{Conclusion}

This study investigated Chinese preservice and in-service teachers' experiences of existing TRCs and expectations of ideal TRCs by using the Smart Classroom Inventory. The results indicated that: (a) both preservice teachers and in-service teachers reported significantly lower experiences of TRCs than their expectations of ideal ones in terms of most dimensions, with the only exception that preservice teachers' Technology usage. (b) Whether in existing TRCs, or in ideal ones, both preservice teachers and in-service teachers reported relative lower scores of Flexibility, Learning data, Differentiation, Investigation, and Cooperation than other dimensions. (c) Preservice teachers reported significantly higher scores of Flexibility, Technology usage, Learning data, Differentiation, Investigation, and Cooperation than in-service teachers, while 
in-service teachers reported significantly higher scores of Physical design, Student Cohesiveness, Equity, and Learning experiences than preservice teachers. (d) Preservice teachers reported significantly higher expectation of ideal Physical design, Differentiation than in-service teachers, while they reported significantly lower expectations of ideal Flexibility, Student Cohesiveness, Equity, and Learning experiences than in-service teachers.

This study contributed to the teacher education area by revealing the differences in views of preservice teachers and in-service teachers on TRCs, which could provide a decision basis for improving both preservice teacher education and in-service professional development. This study also contributed to educational informatization community by revealing the gap between the existing TRCs and ideal TRCs from the perspective of both preservice teachers and in-service teachers, which could provide a direction for optimizing TRCs design.

\section{Acknowledgements}

This work was funded by the Chinese Ministry of Education Humanities and Social Science Foundation under projects number $14 \mathrm{YJC} 880025$.

\section{References}

Ahmad, C. N. C., Osman, K., \& Halim, L. (2013). Physical and psychosocial aspects of the learning environment in the science laboratory and their relationship to teacher satisfaction. Learning Environments Research, 16(3), 367-385.

Bocconi, S., Kampylis, P., \& Punie, Y. (2012). Innovating teaching and learning practices: Key elements for developing creative classrooms in Europe. eLearning Papers, 30, 1-13.

Chen, N.-S., Cheng, I.-L., \& Chew, S. W. (2016). Evolution is not enough: Revolutionizing current learning environments to smart learning environments. International Journal of Artificial Intelligence in Education, 26(2), 561-581.

de Winter, J., Winterbottom, M., \& Wilson, E. (2010). Developing a user guide to integrating new technologies in science teaching and learning: Teachers' and pupils' perceptions of their affordances. Technology, Pedagogy and Education, 19(2), 261-267.

Dinçer, S. (2018). Are preservice teachers really literate enough to integrate technology in their classroom practice? Determining the technology literacy level of preservice teachers. Education and Information Technologies, 23(6), 2699-2718.

Dwyer, D. C., Ringstaff, C., \& Sandholtz, J. H. (1991). Changes in teachers' beliefs and practices in technology-rich classrooms. Educational Leadership, 48(8), 45-52.

Elstad, E., \& Christophersen, K.-A. (2017). Perceptions of digital competency among student teachers: Contributing to the development of student teachers' instructional self-efficacy in technology-rich classrooms. Education Sciences, 7(1), 27.

Fuad, M., Deb, D., Etim, J., \& Gloster, C. (2018). Mobile response system: A novel approach to interactive and hands-on activity in the classroom. Educational Technology Research and Development, 66(2), 493-514.

Gummer, E., \& Mandinach, E. (2015). Building a Conceptual Framework for Data Literacy. Teachers College Record, 117(4), n4.

Hansen, D. T. (2002). Dewey's conception of an environment for teaching and learning. Curriculum Inquiry, 32(3), 267-280.

Hare, J. C., Ault, M., \& Niileksela, C. (2011). The Influence of Technology Rich Learning Environments: A Classroom-based Observational Study. Society for Information Technology \& Teacher Education International Conference, 4304-4311. Association for the Advancement of Computing in Education (AACE).

Hwang, G.-J., Chu, H.-C., Shih, J.-L., Huang, S.-H., \& Tsai, C.-C. (2010). A decision-tree-oriented guidance mechanism for conducting nature science observation activities in a context-aware ubiquitous learning environment. Journal of Educational Technology \& Society, 13(2), 53-64.

Inan, F. A., \& Lowther, D. L. (2010). Factors affecting technology integration in K-12 classrooms: A path model. Educational Technology Research and Development, 58(2), 137-154.

Kennedy-Clark, S. (2011). Pre-service teachers' perspectives on using scenario-based virtual worlds in science education. Computers \& Education, 57(4), 2224-2235. 
Lemmon, C., Lui, S. M., Cottrell, D., \& Hamilton, J. (2012). Challenges to develop an interactive 3D virtual world for psychological experiments. Proceedings of the European Conference on Games Based Learning, 278-284.

Lewin, K. (1946). Behavior and development as a function of the total situation.

Li, B. (2015). The Study towards the Influence Factors for Teachers' Choice of Innovative Teaching Methods in the Smart Classroom. Teacher Education Research, (3), 50-55.

Li, B., Kong, S., \& Chen, G. (2015). Development and validation of the smart classroom inventory. Smart Learning Environments, 2(1), 3. https://doi.org/10.1186/s40561-015-0012-0

Liao, M.-Y., Sunq, C.-Y., Wang, H.-C., \& Lin, W.-C. (2019). Virtual Classmates: Embodying Historical Learners' Messages as Learning Companions in a VR Classroom through Comment Mapping. 2019 IEEE Conference on Virtual Reality and 3D User Interfaces (VR), 163-171. IEEE.

Lin, Y.-T., Huang, Y.-M., \& Cheng, S.-C. (2010). An automatic group composition system for composing collaborative learning groups using enhanced particle swarm optimization. Computers \& Education, 55(4), 1483-1493.

Liu, M., Horton, L., Olmanson, J., \& Toprac, P. (2011). A study of learning and motivation in a new media enriched environment for middle school science. Educational technology research and development, 59(2), 249-265.

Mandinach, E. B., \& Gummer, E. S. (2013). A Systemic View of Implementing Data Literacy in Educator Preparation. Educational Researcher, 42(1), 30-37. https://doi.org/10.3102/0013189X12459803

Moore-Russo, D., Viglietti, J. M., Chiu, M. M., \& Bateman, S. M. (2013). Teachers' spatial literacy as visualization, reasoning, and communication. Teaching and Teacher Education, 29, 97-109.

Nichols, S. (2011). Young children's literacy in the activity space of the library: A geosemiotic investigation: Journal of Early Childhood Literacy. https://doi.org/10.1177/1468798411399275

Niemi, H. (2002). Active learning-A cultural change needed in teacher education and schools. Teaching and Teacher education, 18(7), 763-780.

O'Grady, A., Simmie, G. M., \& Kennedy, T. (2014). Why change to active learning? Pre-service and in-service science teachers' perceptions. European Journal of Teacher Education, 37(1), 35-50.

Omokawa, R., Kobayashi, M., \& Matsuura, S. (2019). Expressing the Personality of a Humanoid Robot as a Talking Partner in an Elementary School Classroom. International Conference on Human-Computer Interaction, 494-506. Springer.

Parkman, S., Litz, D., \& Gromik, N. (2018). Examining pre-service teachers' acceptance of technology-rich learning environments: A UAE case study. Education and Information Technologies, 23(3), 1253-1275.

Pierce, R., \& Ball, L. (2009). Perceptions that may affect teachers' intention to use technology in secondary mathematics classes. Educational Studies in Mathematics, 71(3), 299-317.

Prensky, M. (2001). Digital natives, digital immigrants part 1. On the horizon, 9(5), 1-6.

Robinson, W. I. (2003). External and internal factors which predict teachers' computer usage in K-12 classrooms. Wayne State University.

Shields, M. (2005). Information literacy, statistical literacy, data literacy. IASSIST quarterly, 28(2-3), 6-6.

Walker, J. D., Brooks, D. C., \& Baepler, P. (2011). Pedagogy and Space: Empirical Research on New Learning Environments. Educause Quarterly, 34(4), n4.

Watson, W. R., Mong, C. J., \& Harris, C. A. (2011). A case study of the in-class use of a video game for teaching high school history. Computers \& Education, 56(2), 466-474.

Yang, J., \& Huang, R. (2015). Development and validation of a scale for evaluating technology-rich classroom environment. Journal of Computers in Education, 2(2), 145-162.

Yang, J., Yu, H., Gong, C., \& Chen, N.-S. (2017). Students' Perceptions and Behaviour in Technology-Rich Classroom and Multi-Media Classroom. Eurasia Journal of Mathematics, Science \& Technology Education, 13(3), 621-647.

Yang, Y., Leung, H., Yue, L., \& Deng, L. (2013). Generating a two-phase lesson for guiding beginners to learn basic dance movements. Computers \& Education, 61, 1-20. 
Yau, S. S., Gupta, S. K., Karim, F., Ahamed, S. I., Wang, Y., \& Wang, B. (2003). Smart classroom: Enhancing collaborative learning using pervasive computing technology. Proceedings of 2nd ASEE International Colloquium on Engineering Education (ASEE2003), 1-10.

Yi, Z., Chao, D., Ge, D., \& Fan, Z. (2010). To construct the architecture of digital learning port for free normal students and analyze the impact on teacher education. International Conference on Technologies for E-Learning and Digital Entertainment, 288-297. Springer.

Zeki, C. P., \& Güneyli, A. (2014). Student teachers' perceptions about their experiences in a student centered course. South African Journal of Education, 34(3), 1-11.

\section{Copyrights}

Copyright for this article is retained by the author(s), with first publication rights granted to the journal.

This is an open-access article distributed under the terms and conditions of the Creative Commons Attribution license (http://creativecommons.org/licenses/by/4.0/). 